\title{
From new paternalism to new imaginings of possibilities in Australia, Canada and Aotearoa/ New Zealand: Indigenous rights and recognition and the state in the neoliberal age
}

\author{
Deirdre Howard-Wagner, Maria Bargh
}

and Isabel Altamirano-Jiménez

\section{Introduction}

The election of Evo Morales as the first indigenous President of Bolivia in 2005 is widely credited to the Cochamba Water War (Spronk 2007: 8). The Cochamba Water War progressed from an indigenous movement and a specific issue to the creation of an indigenous political party and election of the first indigenous President. The Bolivian water war, the Puebla Panama Plan in Mexico, the Mackenzie Valley pipeline in Canada (Altamirano-Jiménez 2004) and Māori resistance to the neoliberal agenda from 1984 onwards (Bargh 2007: 26) inspired much theorising about indigenous people successfully contesting neoliberalism (AltamiranoJiménez 2004, Bargh 2007, Spronk 2007: 8, Postero 2007). Bargh and others, for example, documented not only 'overt Māori resistance to neoliberal policies, but also more subtle stories of activities, which 
implicitly challenge neoliberal practices and assumptions by their support for other ways of living' (Bargh 2007: 1). Scholars make visible the persistence of the colonial in the concrete and material conditions of everyday neoliberal governance and life (Howard-Wagner \& Kelly 2011: 103). As Bargh (2007), Altamirano-Jiménez (2013), Howard-Wagner (2010b, 2015) and others note, indigenous categorisations of neoliberal practices as a form of colonisation relate to a concern that neoliberalism in its multiple forms poses a threat to indigenous ways of life. This scholarship also critically reflects on the reshaping of the relationship between the state and indigenous peoples under neoliberalism (Altamirano-Jiménez 2004, Bargh 2007, Howard-Wagner 2009). For example, it draws attention to the increasing intervention in the lives of indigenous peoples (Howard-Wagner 2007, 2009, 2010a, 2010b) and the dispossession of indigenous people through privatisation (Wolfe 2006, Howard-Wagner 2012, Altamirano-Jiménez 2013, Coulthard 2014). It does not, however, preclude agency, resistance and decolonisation.

Interpretive micro-studies about indigenous peoples' engagement with neoliberalism provide particular value. They tell us about actually existing neoliberalism in the context of intervention in the everyday lives of indigenous peoples, contests over rights, contests over policy and the complex decisions indigenous people are making about how to protect their rights and navigate diverse economies involving neoliberal policies and practices.

\section{Ngāti Tūwharetoa and the Mighty River Power}

The area of water management in New Zealand is an example of these complex decisions.

Successive New Zealand governments have argued that 'no one owns water'; however, in the agriculture sector farmers can trade water permits and water bottling companies make significant profits based on water's zero cost (Young 2012). The Waitangi Tribunal has acknowledged Māori arguments that they continue to have customary rights to water and has stated that Māori have proprietary rights in water (Waitangi Tribunal 2012). 
One tribe in the central North Island, represented by the Tūwharetoa Māori Trust Board, has signed a commercial arrangement with partially stateowned enterprise Mighty River Power (Bradley 2014). The Tūwharetoa Māori Trust Board has the legal right to charge commercial users of Lake Taupō for water. Their legal right stems from their customary rights and was reaffirmed in 1992 and 2007 (New Zealand Government 2007). On the face of it, the commercial arrangement looks like an adoption of the commodification of water. However, there are several elements that complicate this oversimplified assessment. One is that the Tüwharetoa Māori Trust Board only proposed the commercial arrangement after the government partially sold the shares in Mighty River Power in order to generate government revenue. Prior to that, the Trust Board allowed for the drawing of water for the public good of generating electricity. In addition, despite the commercial arrangement, the Trust Board is focused on improving water quality and remains intent on protecting the water as a treasure, 'for the benefit of our future generations' (Tūwharetoa Māori Trust Board 2017).

\section{'Actually existing neoliberalism'}

How neoliberalism manifests in different contexts is where discussions about the enabling and constraining aspects of neoliberal governance in the context of indigenous peoples become extremely useful. This is one of the objectives of this edited collection and what sets it apart. It draws out policy coherence in three liberal settler states, Australia, Canada and New Zealand, but also exposes the idiosyncratic operational dynamics of neoliberal governance within and between these countries. Individually, the empirically grounded, interpretive micro-studies thus provide particular value. Read together, however, this collection broadens the debate and the analysis of contemporary government policy. This collection also gets away from the standard focus on resource development and land rights and into intense and complex matters of social policy, disability policy and the like.

Thus, one of the objectives of this collection as a whole is to reveal both the particularities of historical-geographical-legal situations, or the forms of 'actually existing neoliberalism' that are 'variegated' by historical, geographical and legal contexts and complex state arrangements (Brenner et al. 2010). At the same time, it presents examples of a more nuanced 
agential, bottom-up indigenous governmentality in which indigenous actors engage in trying to govern various fields of activity, both by acting on the conduct and contexts of everyday neoliberal life, and by acting on the conduct of state and corporate actors as well (Barnett 2005: 10).

Further, this collection aims to reveal the highly variegated features, impacts and outcomes of neoliberalism (Fine \& Saad-Filho 2017: 695). It does so in an original way, by juxtaposing broader global dynamics through a variety of comparative interpretative perspectives. Importantly, read together, the collection reveals the different features and outcomes of neoliberalism in Australia, New Zealand and Canada, but also how neoliberalism redefines the relationship between the economy, the state, society and indigenous people in different social policy contexts within these nation states; that is, how it gives rise to the (variegated) neoliberalisation of everyday life (Fine \& Saad-Filho 2017: 697). It does so by drawing together disparate national and disciplinary perspectives, providing valuable insights into hitherto little-known areas of public policy and indigenous activism, and offering a sustained and coordinated critique of the status quo.

Together, the essays reveal levels of contingency and context-specific variation. The collection thus leans towards a Foucauldian approach as it is more attuned to the contingency and unanticipated consequences of neoliberal agendas' (Barnett 2005: 8). Importantly, when you put a collection of disparate, short essays together, the definitional context can often be missing. This introduction does a lot of the groundwork for the collection, providing much of the context and definitional background that is needed, as well as teasing out the constraining and enabling aspects of neoliberal governance in different contexts. It pulls the collection together, giving the reader important background knowledge so that the reader can gain more from the collection as a whole. The objective of Chapter One is to explain the approach adopted, then draw out some of the key themes from the chapters within this collection, contributing to the overarching purpose or thesis of the book. This is followed by an outline of the organisation of the book. First though, we briefly revisit the debates about the value of neoliberalism as an analytic tool: a point also taken up by various authors within this collection, such as Will Sanders, Patrick Sullivan and Dominic O'Sullivan. 


\section{Neoliberalism and the deep contests over its value as an analytic tool}

We are mindful of the expansive literature on neoliberalism, its usefulness as a concept, and an equally prominent debate around the best understanding of contemporary indigenous politics in the neoliberal age. Our aim is to present both sides of the coin, bringing into consideration a more agential turn (Bargh 2007, Howard-Wagner 2006, 2012).

With regard to the deep contests over neoliberalism's value as an analytical tool, challenges to the use of the term neoliberalism concern its application as a concept of universal relevance: the idea that neoliberalism, if it is to be worthy, needs to be shown as applicable universally. Such a challenge suggests that 'neoliberalism is everywhere, but at the same time, nowhere' (Venugopal 2015: 165). The purpose of this argument is that it serves as the death knell for neoliberalism, watering down its analytical potency. This argument emerges from the tendency to equate neoliberalism with laissez faire and 'assume that a strong and direct correlation exists between the normative prescriptions of neoliberal theory, and neoliberalism in practice' (Cahill 2010: 305). The economic project of the state in the neoliberal age is conceptualised as essentially non-interventionist, involving less government, and as laissez faire. ${ }^{1}$ Importantly, what scholars such as Damien Cahill, and others (e.g. Brenner et al. 2010), have done is to distinguish between neoliberalism in theory and practice, turning their attention to 'actually existing neoliberalism' (Cahill 2010: 305). The point that Cahill is making is that 'for actually existing neoliberalism to come to an end would require an end to, or the undermining of, one or more of the following processes: deregulation, privatisation or marketisation' (Cahill 2010: 309). It would, for example, as Cahill also notes 'require limits placed upon the freedoms of capital gained under neoliberalism ... and social protections that quarantine individuals from market dependence, and ... a shift in the balance of class forces in favour of labour (Cahill 2010: 309).

1 Social scientists first engaged with neoliberalism as a liberal project aimed at economic freedom. Thus, many also argued that neoliberalism had at its centre a critique of the state, particularly the 'excesses, inefficiencies and injustices of the extended State, and the alternatives posed in terms of the construction of a "free market" and a "civil society" in which a plurality of groups, organizations and individuals interact in liberty' (Rose and Miller 1991). 


\section{So, why do we refer to the neoliberal state?}

Social scientists have long been concerned with an over-valuing of the problem of the state in the context of 'actually existing neoliberalism', turning their intention instead to the action of governing. Increasingly too, social scientists turn to analysing neoliberal projects or solutions as not simply economic projects, but also social projects that produce specific outcomes, particularly in the context of the reforming of the social state systems and social strategies of the state (e.g. Brown 2003, Harvey 2006, Wacquant 2009, 2010). As Cahill notes, 'it has been demonstrated that the state has maintained a pervasive presence in the regulation of economic and social life during the last three decades, thus contravening a key normative prescription of neoliberal theory' (Cahill 2010: 305). In practice then, while the role of the state has changed from the direct deliverer of services, the regulatory apparatuses of the state have not been diminished (Cahill 2010: 305).

What we are talking about then is the predilection for neoliberal solutions (Cahill 2010: 309) in everything from wicked social problems to water management. What is more, we are interested in revealing the complexities of how indigenous people engage with 'actually existing neoliberalism'. For example, how indigenous people protect their rights and navigate this predilection for neoliberal solutions.

Alongside this, there is growing body of scholarship that examines the racialised effects of neoliberalism (Goldberg 2002, 2009, Winant 2004, Razack 2008, Soss et al. 2011), particularly in the context of indigenous peoples (Howard-Wagner 2006, 2010b, 2012, 2017, Moreton-Robinson 2009). This is also taken up by authors within this collection, such as Shelley Bielefeld and Alex Page.

\section{The '(variegated) neoliberalisation of everyday [Indigenous] life'}

While the broad aim was to stimulate thinking about indigenous policy in the neoliberal age, the contributors to this volume vary in their engagement with the theme of indigenous rights, recognition and the state in the neoliberal age. This collection represents how ad hoc rationalisations and different political projects of neoliberalism can manifest as contradictory (Larner et al. 2007). The impact of neoliberalism in specific communities is shaped by different geographies, histories and material circumstances. 
The reorganisation of the state and its functions has been welcomed by some indigenous communities. For others, its highly interventionist and devastating effects have entailed a radical erosion of recognition of status and rights.

\section{Neoliberalism as shaping and constraining forms of recognition on offer}

Many of the authors within this collection explain how 'actually existing neoliberalism' has shaped and constrained the forms of recognition on offer from the state (in the case of Australia and Canada) and the Crown in (Aotearoa/New Zealand). ${ }^{2}$ Avril Bell, for example, reminds us that:

At its Hegelian roots, recognition theory is about the struggle to achieve a relationship of equals between two subjects. To recognise subjectivity of another is to recognise their equal and autonomous status as selfdetermining people worthy of respect (Bell this volume, Chapter 4).

What predominates is what Jakeet Singh calls 'recognition from above' whereby 'the state is the arbiter of just and unjust claims for recognition from subordinate groups' (Singh 2014: 47, Williams 2014: 8). Besides being the arbiter of recognition, the state also defines the terms of recognition. For example, although the state has legally recognised indigenous identity and rights, identity and rights are essentialised in ways that facilitate the economic interests of the state in the neoliberal

2 The Crown is used in New Zealand broadly to mean the state as a whole. There is no precise definition in New Zealand law, although it is defined in the Crown Proceedings Act 1950 and the Public Finance Act 1989. The interpretation in the Crown Proceedings Act 1950 states: 'The Sovereign or the Crown means the Sovereign in right of his or her government in New Zealand'. The Public Finance Act states that the 'Crown or the Sovereign - a) means the Sovereign in right of New Zealand; and $\mathrm{b}$ ) includes all Ministers of the Crown and all departments'. The definition goes on to exclude a number of entities including an Office of Parliament, a Crown entity and a state enterprise.

For many Māori, the term 'the Crown' invokes reference to the partnership between the English and Māori in the Treaty of Waitangi 1840. Contestation over the definition occurs for Māori therefore when trying to argue where Treaty of Waitangi obligations lie. As Bell's chapter illustrates, the question of whether local government in New Zealand is part of 'the Crown' and has legal obligations to Māori continues to be debated. There are other legal debates within New Zealand about which branches and mechanisms of the state might be considered agents of the Crown for the purposes of describing breaches of the Treaty of Waitangi in the Settlements process (see Williams 1999: 234-5 and Shore \& Kawharu 2014). 
age. Moreover, while indigenous identity is recognised, the complex articulation of indigenous peoples' inclusion in the neoliberal economy attempts to foreclose other alternatives.

Chapters within this collection also examine how local arrangements in which indigenous peoples are the agents of recognition (Coulthard 2007: 456), and thereby have greater control over the redistributive impact of revenues and expenditures to address indigenous peoples' social exclusion, can promote indigenous peoples' social inclusion and address disadvantage. That is, how 'recognition from below' occurs 'when people in dominated social positions turn away from institutionalised power hierarchies, shaping their own social orders without approval or permission of any authority beyond themselves' (Williams 2014: 10). As Williams notes, 'These processes of self-constituting power, realised (inter alia) through acts of resistance or through prefigurative political movements, also entail struggles for recognition, but the agents of recognition are [Indigenous peoples]' (ibid.). Thus, what Glen Coulthard defines as 'recognition from below' is an important consideration. Coulthard defines this as the:

practices of 'self-recognition' through which dominated or colonised subjects 'critically revalu[e], reconstruct $\ldots$ and redeploy ... culture and tradition' and, in the process, radically transform their own selfconsciousness as political agents (2007: 456, cited in Williams 2014: 10).

Importantly, many of the authors within this collection examine the complex trajectories of neoliberalism, highlighting how it contains and constrains different political, economic and social possibilities, while also explaining and understanding the alternative political, economic and social possibilities the neoliberal age offers.

They also consider how neoliberal governance often entails a shift in state recognition, considering this shift and what is needed to create contexts in which recognition from below is possible. For example, in this collection Will Sanders argues-in the context of Australia, but applicable to New Zealand and Canada — that ' $[\mathrm{w}]$ hat is needed in contemporary Australian Indigenous policy is some re-recognition of the attempt at decolonisation and the contribution that a peoples approach can make'. Sanders gives more detailed consideration to this proposition in relation to the 10 years of federal Indigenous affairs in Australia after the abolition of the Aboriginal and Torres Strait Islander Commission (ATSIC). Rather than neoliberalism, the broad sociological term Sanders finds most helpful in Australian Indigenous affairs is decolonisation. As Sanders writes, he 
'resist $[\mathrm{s}]$ the term neoliberalism as it seems to foreclose, rather than open, possibilities'. Sanders argues, ' $[\mathrm{w}]$ hile there is no denying the rise of market liberalism in ideas about government since the 1980s, other ideas have also still had a presence, such as decolonisation and a "peoples" approach'. He goes on to propose that '[f]raming and labelling are important, and it may be that insisting that this is still the age of decolonisation, as well as neoliberalism, is a way to keep alive ideas about the recognition of Indigenous rights'.

This too concerns the state and changing game plans, but also the nuances and complexities of changing game plans, in relation to indigenous rights and recognition in the neoliberal age (Bargh 2006).

\section{The neoliberal state and the United Nations Declaration on the Rights of Indigenous People}

It is important to situate the constraints of the neoliberal age in the context of formal international recognition of indigenous rights. Recent developments in international law indicate that states and international institutions have finally become responsive to indigenous peoples' demands. The ratification of the United Nations Declaration on the Rights of Indigenous Peoples (UNDRIP) in 2007 constitutes a landmark, setting the standards for the treatment of indigenous peoples by the state. ${ }^{3}$ Although UNDRIP can be understood as a counter balance to state power, the duties of states and other actors are embedded in neoliberal governance rationalities (Lindroth 2014: 342). The provisions in UNDRIP are both liberal and anti-colonial in that they advance indigenous peoples' freedom to pursue economic, social and cultural development. From this point of view, the right to culture simultaneously pushes the human rights paradigm, by explicitly centring self-determination, and reproduces individual civil and political rights.

The right to indigenous self-determination has been considered to be the main tenet and symbol of the indigenous movement (Daes 2003: 303). However, the meaning of indigenous self-determination is not only

3 For the full text of the United Nations Declaration of the Rights of Indigenous Peoples, see www. un.org/development/desa/indigenouspeoples/declaration-on-the-rights-of-indigenous-peoples.html. 
contested but resisted by many states. Although UNDRIP seems to push the envelope in articulating indigenous self-determination, it limits this right to the extent and format that the international community of states has supported. As far as the indigenous peoples' claim to self-determination is concerned, Article 3 of UNDRIP states: 'Indigenous peoples have the right to self-determination. By virtue of that right they freely determine their political status and freely pursue their economic, social and cultural development'. In responding to governments' objection to this right, Article 46(1) notes:

nothing in this Declaration may be interpreted as implying for any State, people, group or person any right to engage in any activity or to perform any act contrary to the Charter of the United Nations or constructed as authorising or encouraging any action which could dismember or impair totally or in part, the territorial integrity of political unity of sovereign and independent States.

This means that indigenous self-determination is qualified as a 'domestic or internal' right that can only be exercised within the boundaries of the state.

Disagreements over the meaning of self-determination and the attempts to bracket it resulted in the failure of states and indigenous peoples to agree on a text for the document. These disagreements were central to Australia, Canada and New Zealand's failure to ratify the Declaration in 2007. These countries noted that UNDRIP was not a suitable basis for developing a binding agreement because it did not reflect customary international law.

Two years later, in 2009, the Australian Government endorsed UNDRIP, followed by New Zealand and by Canada in 2010. Canada's endorsement emphasised the fact that UNDRIP is 'aspirational' and that this country would interpret this document in a manner consistent with its national laws. Similarly, Australia noted that, while UNDRIP was non-binding, it remained a set of important principles for states to aspire to. Whereas New Zealand stated that its endorsement was limited by its legal and constitutional frameworks. In reversing their initial rejection, these states 'selectively endorsed' (Lightfoot 2012) UNDRIP, reflecting their willingness to support cultural rights but not indigenous selfdetermination as it connected to land and natural resources. Moreover, it reflects states' interest in engaging in intergovernmental relations and negotiations with indigenous peoples outside the sphere of rights. What 
has been termed the 'implementation era' (Gover 2015) is characterised by how agreements and settlements between settler governments and indigenous peoples are operationalised within the legal frameworks of the state. This era started in the early 1990s, in the context of neoliberal restructuring, and has dealt with matters of property and jurisdictions. In this context, the delegation of services delivery has been instrumental to the creation of partnerships with the private sector. As several of the contributors show, these processes of service delivery brought indigenous people and organisations into the neoliberal market.

Influenced by the Truth and Reconciliation Commission of Canada's Calls for Action explicitly calling upon the government to fully endorse UNDRIP, in 2016 newly elected Prime Minister Justin Trudeau eliminated Canada's objections to the Declaration. However, indigenous organisations and advocates have criticised the Trudeau Government for not implementing UNDRIP. Cree MP Romeo Saganash introduced a Bill to harmonise Canadian laws with UNDRIP. Parliament has not voted on this Bill and Prime Minister Trudeau has not fully supported the Bill, arguing UNDRIP could not be supported word by word (Barrera 2017).

Although UNDRIP sets minimum standards for the treatment of indigenous peoples and enhances the significance of human rights norms, another central theme that deserves consideration is the contradictory coexistence of both recognition of status and rights and economic development. On the one hand, UNDRIP has legitimated human rights as the predominant language for making social justice claims. On the other, it conceives of freedom and the realisation of self-determination primarily through the market economy. Because of the exceptional status of indigenous people, international law is founded on a specific understanding of their cultural survival attached to land and traditions. The acknowledgement of the impact of colonialism becomes about the elimination of impediments to the right to economic development. This apparent contradiction is productive. It simultaneously produces the neoliberal indigenous subject and an indigenous identity that looks back, framing indigenous peoples as always in need of intervention (HowardWagner 2006, 2009, Altamirano-Jiménez, 2014). As Clarke notes, when neoliberalism produces cultural difference, it does so by fragmenting existing meanings and enabling new possibilities for the state (Clarke 2004). By privileging specific types of knowledge, language, cartographic representations and legal traditions, the language of rights has produced indigenous peoples as a distinctive category that requires particular kinds 
of measures (Altamirano-Jiménez 2014, Lindroth 2014). Moreover, because the state is the grantor of rights, one way its power is manifested is in deciding who qualifies for rights and who meets the standards to be recognised as indigenous. In this context, while the law requires indigenous peoples to meet certain standards, failure of indigenous peoples to fully participate in the market is conceived of as an anomaly that can be changed. Indeed, interventions are justified in the name of rights and 'improving' people's lives (Li 2010: 388). As peoples in disadvantage and under threat, indigenous communities require special measures, justifying states' intervention in their lives. The chapters in this collection show interventions are prompted by the social, economic and cultural conditions of indigenous peoples. As Yap and Yu note in their chapter, such conditions are measured in relation to a good market in which having a job, living a healthy lifestyle and being able to consume become markers of success. Similarly, Isabel Altamirano-Jiménez demonstrates that, while the introduction of matrimonial property rights on reserves in Canada is represented as a way to exercise the right to development, indigenous people are blamed for their circumstances and the 'backwardness' of their cultures.

\section{Rethinking and revaluing indigenous economies vs winding back indigenous rights}

Maria Bargh, and many of the authors within this collection, call for a rethinking and revaluing of indigenous economies, especially the economy of indigenous rights, including how indigenous people act as economic actors; the multiple economic, social and cultural activities that indigenous people engage in as economic actors; and the public value that indigenous people, organisations and communities contribute to the economy and society. This approach creates new imaginings of possibilities.

This is not to say that indigenous rights cannot exist within the context of the market-a point taken up in a number of the chapters within this collection. Historically excluded, indigenous peoples are encouraged to integrate into the global economy and realise their newly recognised rights to development via the market and self-government, which fit well with the reduction of the state and the transfer of administrative responsibilities. 
Although recognition of indigenous self-government is observed in Canada and New Zealand, recognition in relation to land and economic development has been far more fraught in Australia. Even so, in New Zealand, the neoliberal age has seen the state (or the Crown, as it is commonly referred to in reference to its role and obligations stemming from the Treaty of Waitangi) deal with Māori in ways that are reminiscent of more longstanding colonial practices of civilising indigenous peoples through market training (Bargh 2007). Since 1984, when the first neoliberal policies were introduced in New Zealand, successive governments have become more firmly supportive of Māori economic development and have rearticulated the Treaty settlements processwhich aims to rectify Crown breaches of the Treaty of Waitangi-to be rather narrowly about the economic development of assets repatriated to Mãori. By characterising the Treaty settlement process in this way, and celebrating Māori economic identities and economic success, the Crown channels Māori aspirations for self-determination into a neoliberal market framework. Accompanying this process is one where Māori are treated as simply one type of actor among many others in the private sector, all with allegedly equal rights to tender for contracts to deliver services or to enter joint ventures with government agencies, such as in forestry. Wider government policies in the areas of housing, social welfare or health continue to treat Māori as subjects that are not entirely capable of governing their own affairs and therefore require training and intervention in their lives. Similar rationalities and dynamics have emerged in Australia and Canada.

Canada also underwent a period of changes and cuts in the 1980s, which were detrimental to the welfare state. Marked by the economic crisis and the political discontent produced by the patriation of the Canadian Constitution in 1982, social policy-making was reoriented towards the goals of economic integration and privatisation, which were seen as the key to domestic wellbeing (Banting 1996, McKeen \& Porter 2003: 125). The neoliberal transformation undermined universality in favour of major reductions in social programs and the transfer of social welfare responsibilities from the federal government to the provinces. Moreover, there was a shift from viewing social support as an entitlement of citizenship to developing policies that emphasise individual responsibility and economic independence regardless of people's status in society (Bashevkin 2003). Although Canadian citizenship has been undermined by neoliberalism, for some indigenous people the recognition of their 
rights in the Constitution and devolution of responsibilities were welcomed, as the welfare state had also been the most interventionist for their communities.

While the state-society relation was being reconfigured, the Canadian Government embarked on the negotiation of North American Free Trade Agreement (NAFTA). To facilitate economic integration, major barriers to resource extraction were lifted. The Canadian Government introduced privatisation of state assets, services, land and resources, with the purpose of creating the conditions for economic integration. Indigenous peoples were encouraged to integrate into the global economy and realise their newly recognised collective rights via the market and selfgovernment, which fit well with the reduction of the state and the transfer of administrative responsibilities. NAFTA paved the way to deepen resource extraction during the Harper administration and the speeding of environmental assessments, and, in turn, indigenous discontent with the scale of resource extraction.

Australia too has gone through many of the shifts and changes experienced in New Zealand and Canada. However, in Australia, the neoliberal age has entailed the winding back of Indigenous rights (Howard-Wagner 2008). What began as former prime minister Howard's assertions in 1996 that the pendulum had swung too far in favour of Indigenous rights, particularly in relation to native title rights and to symbolic gestures and special measures (Howard-Wagner 2006), developed into a complex hybridisation of neoliberal strategies that today target every dimension of Aboriginal life, from social security payments and school attendance to the way that Aboriginal organisations do business. Importantly, in the Australian context, the abolition of ATSIC, the Northern Territory Emergency Response, income management (e.g. the cashless welfare card), the announced closure of Aboriginal homelands in the Northern Territory and later Western Australia, the Indigenous Advancement Strategy, the new mainstreaming, market training and the overall heightened state governmentality in the name of Indigenous improvement can be understood as actions of government in the neoliberal age. Authors refer to such political moments in the governing of Indigenous affairs in Australia in the first and second sections of the collection.

Contradictorily then, rather than less government, the turn towards individual indigenous wellbeing and poverty governance in the neoliberal age has entailed a turn away from self-governance and freedom of the rights/ 
welfare state era and return to government intervention and intrusion into private lives of indigenous people and the affairs of indigenous people in all three countries. This is one of the major contradictions of neoliberalism. That is, as Nadesan notes in citing the work of Mitchell Dean (2002: 129), while purporting to govern through individual freedom, neoliberal governance:

employs diverse and heterogeneous forms of power to establish and preserve 'a comprehensive normalisation of social, economic and cultural existence' and thus the state 'attempts to govern as much through "domination"- a word that covers a myriad of conditions - as it does through freedom' (Nadesan 2008: 35).

Drawing too on the work of Mitchell Dean, Nadesan goes on to note that 'normalisation ... does not necessarily entail therapeutic adjustment but rather, containment and extrication of risk ... Concerns for "responsibility" and "obligation" outweigh freedom and rehabilitation' (Nadesan 2008: 35).

At the same time, the assumption that indigenous communities' dysfunction can be solved by participating in the economy continues to undermine other possibilities. Authors in this collection draw attention to the ways that neoliberal governance in Australia, Canada and New Zealand colonises the indigenous domain. For example, Louise Humpage and Fiona McCormack illustrate how, increasingly, Māori are recognised as economic actors and as 'private sector', but at the same time Mãori risk erosion of culture by participating in neoliberal policies. Maria Bargh, Louise Humpage and Dominic O'Sullivan illustrate how neoliberalism has simultaneously provided opportunities and inhibited Māori rights. Louise Humpage also explains how compromises made by Māori for specific and discrete gains may further embed neoliberalism.

\section{Land, privatisation and territorial reorganisation}

There are also authors within this collection, such as Isabel AltamiranoJiménez and Cathy Eatock, who contribute in critical ways to our understandings of the role of Western conceptualisations of property and land to create 'governable' indigenous spaces under neoliberalism. 
So, although the negotiation of land claim agreements opened the space for contemporary political arrangements of self-administration, indigenous communities have struggled, to different degrees, to use such framework to build their own economic capacity. Then again, indigenous participation in the economy and economic development is also commonly misread as neoliberal co-option. Importantly, as many of the authors in this collection remind its readers, indigenous economic aspirations did not suddenly arise in the neoliberal age. The chapters within this collection highlight such complexities.

In Canada, privatisation has been central to territorial reorganisation and the devolution of risk and responsibilities to indigenous communities. Government policies actively encourage private-public partnerships with industry, assuming indigenous communities and industry are equal. Because these partnerships are considered private, they lack accountability. As Altamirano-Jiménez shows in this collection, the combination of private property and indigenous women's rights has become a technology of governance that not only delegates both risks and responsibilities onto indigenous peoples, but also attempts to contain their resistance to such policies. Privatisation is not only reconfiguring indigenous territories and producing different regimes of resource management, but also exacerbating the trend of land and resource appropriation (AltamiranoJiménez 2013, Pasternack 2015). As Altamirano-Jiménez further demonstrates, discourses of responsibility and efficiency to impose private property conceal past and current processes of land dispossession and territorial reorganisation.

In the Australian context, the territorial reconfiguration of land usage and tenure in Australia's Northern Territory facilitated Western conceptualisation of entrepreneurial initiatives, through the move away from community-based approaches to land management and ownership to a model of individual housing/leasehold tenure (Howard-Wagner 2012: 234). This was one of the key features of the Northern Territory Emergency Response laws. That is, the Australian Government changed and introduced various laws in relation to access to Aboriginal land in Australia's Northern Territory through a provision known as a 'whole of [Aboriginal] township lease' to 'attract investment, increase access to home ownership and help local business to prosper' (Australian Government 2011). The whole-of-township lease has also been aimed at increasing business and economic development in Indigenous townships. The Housing Precinct leases established under the joint AU\$672 million 
Strategic Indigenous Housing and Infrastructure Program (SIHIP) in 2009 by the federal and Northern Territory governments, for example, set up a framework for individual private property ownership through building houses and introducing market-based rents and normal tenancy agreements (Howard-Wagner 2012: 234). In this collection, Cathy Eatock illustrates how employment and home ownership objectives are also imposed at the expense of cultural survival in the context of recent policy changes in the Australian state of Western Australia, under the Resilient families, strong communities: A roadmap for regional and remote communities report, which could potentially result in the closure of around 120 smaller remote communities in Western Australia.

\section{Neoliberal governance, welfare responsibilities and domestic wellbeing}

We can establish certain patterns associated with neoliberal governance, such as markets regulating economic activity, welfare responsibilities being transformed into commodity forms that are regulated according to market principles, economic entrepreneurship replacing old forms of regulation and active individual entrepreneurship replacing the passivity and dependency of responsible solidarity (Rose \& Miller 1991: 198). Over time, social policy-making reoriented towards the goals of economic integration and privatisation, which were seen as the key to domestic wellbeing (Banting 1996, McKeen \& Porter 2003: 125). This also entailed a restructuring of welfare and social services through a form of market managerialism.

Importantly, at the same time, a shift has occurred from viewing social support as an entitlement of citizenship to developing policies that emphasise individual responsibility and economic independence, regardless of peoples' status in society (Bashevkin 2003, Brodie 2008). In Australia, New Zealand and Canada, the social contract of the modern welfare state has been undermined by neoliberalism. Furthermore, for some social groups, such as indigenous people, the neoliberal state has been highly interventionist. 


\section{Neoliberalism and paternalism}

The intersectionality between neoliberalism and paternalism, associated with the disciplinary turn embodied in the processes and practices of governing through neoliberal paternalism, is pointed to in several chapters in this collection (Howard-Wagner 2017). In making this argument, authors in this collection demonstrate how neoliberal technologies are deployed to govern the lives of indigenous peoples. In this regard, we see how neoliberal concepts like normalisation, mainstreaming, mutual obligation and conditionality come into play in the governing of indigenous communities, organisations and individuals in the neoliberal age.

This is very much a significant characteristic of the social projects of neoliberalism in Australia, Canada and New Zealand, and elsewhere. While governments still provide government benefits and pensions and social services, they have, for example, provided incentives for, and encouraged, citizens to rely on superannuation funds and private health funds, rather than 'old age pensions' or 'medicare'. Accessibility to and eligibility for government benefits and pensions has also changed around issues of universality and entitlement. This is a point taken up by Karen Soldatic and Shelley Bielefeld in this collection. A key government objective is to move people from welfare to work, and in order to target the employment gap among disadvantaged groups, introducing stronger conditionality is a prominent government strategy. Soldatic draws our attention to the effect that this has had on those Aboriginal and Torres Strait Islander people with disabilities who live in regional parts of Australia.

It is passive welfare populations, also known as the poor and disadvantaged, who are the target of neoliberal social projects (Howard-Wagner 2017). The socio-economic conditions of the poor/disadvantaged individual are the target of intervention (i.e. lack of education, training and employment, lack of parenting skills). The multitude of interventions span from parenting programs that aim to train indigenous parents to be 'good parents' to those that require senior managers of indigenous organisations to undertake governance and leadership training to acquire 'good governance'. It also entails the increased use of nudge policy or behavioural economics that steer the choices that individuals make; or, even worse, the paternalistic forms of conditionality, such as conditional cash transfers, that regulate individual behaviour, and, if necessary, manage 
an individual's income, tying support to certain conditions of appropriate behaviour. Government funding to the frontline social service sector, too, explicitly targets individuals through highly prescribed eligibility criteria.

A number of the authors within this collection describe how individuals rather than structural inequalities are framed as the problem, including Shelley Bielefeld, Louise Humpage, Dominic O'Sullivan and Maria Bargh. In the Australian context, for example, governing through Indigenous disadvantage has not only permitted the neoliberal state to reduce Aboriginal and Torres Strait Islander peoples to a socioeconomically disadvantaged group or sub-population ('the Indigenous population') within the wider Australian population, but has also enabled the neoliberal state to reconfigure the way it recognises the rights of Aboriginal and Torres Strait Islander peoples. This has limited the possibility of Indigenous intervention, dispossessing Aboriginal and Torres Strait Islander peoples of their rights, and ignoring different social histories and divergent social locations, and past and present effects of discriminatory treatment (Howard-Wagner 2017). Mandy Yap and Eunice Yu take this up in their chapter in the context of indigenous wellbeing, noting that this idealised vision measures and evaluates all domains of society according to 'good market' indicators: a good job, healthy lifestyle and consumer rationality. This relationship-between the governing of poverty, passivity and dependency on welfare in terms of defining poverty or disadvantage and wellbeing, managing eligibility, and managing the poor more generally-is thus an important theme running through this collection.

\section{From precarity to poverty governance in the neoliberal age}

Several authors within this collection also highlight the precarious experience of indigenous people in the neoliberal age. Karen Soldatic and Shelley Bielefeld draw our attention to precarity associated with accessibility to government benefits, while Daphne Habibis, Patrick Sullivan, Deirdre Howard-Wagner and Alexander Page draw our attention to precarity associated with insecure funding arrangements and competitive processes for Aboriginal organisations.

This examination moves beyond precarity to investigate how new forms of mutual obligation introduce new forms of subjectification, different from those estalished by welfare state policy, and how this relates to 
a preoccupation with poverty governance in the neoliberal age (HowardWagner 2006, 2017). Mutual obligation is based on the precepts of extending and disseminating market values to social institutions; its objective is to empower the individual to govern themselves as a rational entrepreneurial actor (Brown 2003: 4). Its target is 'passive welfare'. Mead (1997: 1) describes mutual obligation-a hybrid model of neoliberalism and service provisioning in which welfare recipients who are party to this form of agreement are bound by certain conditions relating to behavioural change-as neo-paternalism because of the intervention and 'close supervision of the poor'. Green also argues that mutual obligation, for example, is a mix of neoliberalism and social interventionism (Green 2002: 33). Behavioural economics that steer the choices made by recipients of government funding (such as Aboriginal communities) or social security, or the paternalistic forms of conditionality, such as conditional cash transfers, that regulate individual behaviour (and if necessary manage an individual's income, tying support to certain conditions of appropriate behaviour) are taken up in Shelley Bielefeld's chapter. Bielefeld shows how the targeting of 'passive welfare' has led to the linking of benefits to outcomes, imposing conditions on the recipients of welfare benefits, and also how this has affected Indigenous welfare recipients-particularly with the rolling out of the Healthy Welfare Card in communities with large numbers of Indigenous welfare recipients such as Ceduna, Kununurra and Wyndham.

Poverty governance in the neoliberal age has manifested as a complex, overt racial project in which indigenous peoples are invented, constituted and assimilated into the neoliberal body politic through the positive paternalistic governing of their disadvantage (Howard-Wagner 2017). Paternalistic poverty governance goes beyond a lack of consent on indigenous peoples' part to being governed in this way (Wilson 2015); it harks back to moments in Australia's colonial past when the Indigenous peoples of Australia were treated as childlike, simple-minded and 'incapable of dealing with financial matters' (Bielefeld 2012: 528). The paternalistic neoliberal state not only assumes the right to interfere in the lives of indigenous peoples, violating their rights and autonomy, but takes a directive and supervisory role in their lives. This is where authors within this collection draw on what Mead (1997) first termed the 'new paternalism' to denote the directive and supervisory approach to governing indigenous poverty/disadvantage in the neoliberal age. Paternalism is being reproduced as the very basis of policy formation, 
which functions as an act of tutelage in the logic of the colonial civilising mission, reinforcing paternalism and, in this case, racial hierarchy (Howard-Wagner 2017). Yet, this is not simply the endless repetition of hierarchical colonial relations. It is a colonising moment in and of itself. The authors within this collection contribute to our understanding of neoliberal interventionism in the context of poverty governance and the racialised effects for indigenous people (Howard-Wagner 2017).

\section{Game changes and 'actual existing neoliberalism'}

Many of the authors draw our attention to how the rules of the social policy game have changed in the neoliberal age. One way that authors draw our attention to the changing rules is through an analysis of the economics of social policy in the neoliberal age, in which markets rather than basic rights forefront social policy agendas. Karen Soldatic examines how disability has shifted from the fringes to the centre of policy in most OECD countries. This is due to a concern about the economic costs of disability to society, which in turn means that the governance of disability is concerned with disability costs; thus, attention turns to disability as welfare and cutting access to (in Australia) the Disability Support Pension (DSP). She examines the new rules of the game in which people with disabilities are now assessed according to work capacity, forcing many off the DSP and onto Newstart Allowance (an Australian government income support payment). She notes how the Commonwealth Ombudsman found that Aboriginal and Torres Strait Islander peoples are significantly disadvantaged under the eligibility rules and criteria. She also highlights the spatial experience of Aboriginal and Torres Strait Islander people with disabilities residing in regional Australia, pointing out how the interstice of disability and regionality creates uneven and differentiated outcomes through heightened exposure to economic insecurity, which is exacerbated through diminished access to the DSP.

Daphne Habibis discusses how changes to Aboriginal housing policy have created markets where markets did not previously exist. She discusses the roles mainstreaming, normalisation and coercion play in the Aboriginal housing policy space. She argues for a hybrid housing model to replace the one-size-fits-all approach, one that allows for improvements in remote housing, but also allows for self-determination and innovation. In making this argument, Habibis highlights the partial success of these neoliberal 
strategies of governance, but she also points to the agency and resistance and determination of Aboriginal people to retain their hard-won land rights and resist the closure of communities.

Social services have also been transformed through the inculcation of enterprising values and market-like relations. That is, governments have restructured the delivery of social services to enable and promote economic competition. Governments have again created markets where markets did not formerly exist (Dean 2004: 161), and have thus extended the market to the social. This is a point taken up by contributors to this collection, such as Avril Bell, Daphne Habibis (as discussed), Deirdre Howard-Wagner, Louise Humpage and Patrick Sullivan. Authors apply this lens to understand the 'quiet revolution in the way government does business with Indigenous organisations' (Vanstone 2005) in Australia compared with New Zealand.

Yet the marketisation of social service delivery, known as new public management (NPM), or 'neoliberal public management' as Patrick Sullivan in this collection calls it, has had different effects in New Zealand and Australia. In New Zealand, focus on contracts and neoliberal distrust of the state's abilities also led to the creation of numerous public-private partnerships with unexpected consequences for Māori groups, many of whom were perceived as 'private' actors. Mason Durie (2004) and Avril Bell (this volume, Chapter 4) make this point in relation Mãori service provision. Bell notes, '[d] evolution, contracting social service provision to private providers, enabled the development of Māori providers contracted to delivery services to their own communities'. In New Zealand, therefore, the Māori rhetoric of self-determination at times had resonance with the neoliberal agenda to outsource government services. Nonetheless, government agencies responsible for Māori development and policy adopted business plans that meant goals and outputs were contracted and purchased. This form of contracting regime resulted in mainly outputs that aligned with, and embedded, neoliberal policies (Kelsey 2005: 83).

Game changes are associated too with standardisation. As Will Sanders notes, the new mainstreaming at a government department level has seen very different Indigenous-specific programs inherited from ATSIC turned into much more standardised versions of general government programs. This new mainstreaming also entails the standardisation of Aboriginal service delivery and Indigenous-specific programs into one-size-fits-all programs; so much so that specialised Indigenous organisations become 
redundant and what becomes important is value for money. This is where mainstreaming meets market rationality. The new mainstreaming differs in that it is not about mainstream services operating alongside Aboriginal services as a form of supplementary service delivery, which was the case in the ATSIC years, but that the new mainstreaming is an apparatus or a technology of neoliberal entrepreneurial governance (Hall 2003: 1). Deirdre Howard-Wagner elaborates on this definition of new mainstreaming, explaining how Indigenous organisations in the Australian city of Newcastle now compete for access to government funding within the mainstream social service market. The new mainstreaming therefore also entails the promotion of competition between Aboriginal and mainstream service providers for funding to deliver services to disadvantaged Aboriginal and Torres Strait Islander peoples. Patrick Sullivan and Deirdre Howard-Wagner propose that this is a consequence of a major game change in Indigenous affairs in Australia associated with standardisation and mainstreaming in the era of NPM.

\section{State modernisation and NPM}

NPM is an international phenomenon, but its generic intent has different local manifestations and it has wide-ranging historical geographies (Peck 2004). Generally, in the 21 st century it has come to be known as more than economic liberalisation and privatisation. It is seen as an agenda of administrative reform and state modernisation in the neoliberal age. NPM has been critical to neoliberal governance of social order, particularly reorganisation of the welfare state and poverty governance.

While in Canada and New Zealand there are emerging signs of co-production of government policy, creative and community-centric approaches to public administration, and a growing acceptance of indigenous autonomy (Coates 2016), the NPM era has had a far grimmer effect on Indigenous organisations in Australia. In the Australian state of New South Wales, apart from the OCHRE Local Decision-Making approach, which has as its unrealised vision co-production and greater autonomy among Indigenous organisations at a regional level, there is no co-production of government policy and no creative and communitycentric approaches to public administration. This could potentially shift with the Australian Prime Minister Turnbull announcing in early 2017 that he would be shifting from transactional government to enablement (Turnbull 2017: 1, Howard-Wagner, in press). 
This shift is critical given the adverse effect of NPM on indigenous organisations (see Sullivan in this volume). For example, it has had negative consequences for autonomous Indigenous organisations in Australia: a point explored in different ways by Patrick Sullivan, Deirdre Howard-Wagner, Alexander Page and Will Sanders. Sanders, for example, illustrates how this is part and parcel of the 'new mainstreaming', which follows the abolition of ATSIC.

This turns our attention to another important thread running through a number of the papers within this collection: the severing of ties with the state in the neoliberal age or, to quote Cathy Eatock in this collection, 'look[ing] beyond the hegemony of the nation state', which turns our attention to both recognition and to the issue of indigenous-state relations as a relationship of dependency.

\section{Indigenous economic development as a pathway to self-determination in the neoliberal age}

Within the collection, the theme of severing ties with the state is taken up in relation to indigenous self-determination. There are two important arguments running through this collection. The first concerns what self-determination fundamentally means to indigenous peoples. The second concerns the pathways that indigenous people pursue to achieve self-determination in the neoliberal age. This turns our attention to the relationship between economic development and self-determination in the neoliberal age. Government agendas in relation to indigenous economic development are suddenly promoting indigenous economic development. On the one hand, Bell nails the problem in this in one sentence: 'Māori economic development is expected to lessen the Māori welfare "burden"'. On the other hand, it happens that this approach fits, to a degree, with indigenous desires for sovereignty/autonomy. Yet McCormack, Bell and Humpage all express reservations about the ways that Mãori are attempting to work with neoliberal practices.

A number of authors within this collection engage with such considerations. For example, Fiona McCormack argues that 'indigeneity may be just as likely to appropriate neoliberalism for its own ends as the other way around'. However, she also notes that, while a space has opened up for indigenous economic development, 'the spaces opened for indigeneity under neoliberalism reflect market rather than democratic rationality' (McCormack 2011: 283). Furthermore, McCormack notes 
that the "'opening of spaces", incongruously, may strengthen the capacity of the state to shape and neutralise opposition'. Avril Bell adds that it does not reflect a distinctly indigenous rationality or value base. McCormack also makes a critical point in relation to how dispossession occurs through the market, quoting Fairhead et al. who argue that those who have valuable assets, but are earning incomes too low to permit social reproduction, inevitably have to sell them' (Fairhead et al., 2012: 243, cited in McCormack this volume). Deirdre Howard-Wagner makes this point too, in relation to Aboriginal organisations in Newcastle.

Patrick Sullivan brings a further consideration, attempting to open up wider discussion in relation to Aboriginal organisations and their role in society, arguing that 'the concept of public value remains a form of contemporary nomenclature that offers an opportunity to make visible the full value of Aboriginal organisations to their publics in a manner intelligible to government'.

So, while dispossession occurs through the market, it also provides a mechanism for achieving self-determination in the neoliberal age. Many of the authors illustrate how indigenous economic development and enterprise offers greater access to self-determination, changing the relationship indigenous peoples have with the state. While Deirdre Howard-Wagner illustrates how the pathway to autonomy and selfdetermination for urban Aboriginal organisations in the Australian city of Newcastle has long been pursued through external partnerships and associations and/or flexible and innovative entrepreneurial solutions (such as social enterprise, asset-building and Indigenous-driven economic development), she argues that economic development offers a way of ending what has become a disciplinary relationship of dependency in which Indigenous organisations now do business in a highly regulatory and disciplinary regime of NPM. The pursuit of economic development comes from a growing indigenous anti-statism in the context of funding dependency, in which Aboriginal organisations, who are distinctly apathetical to the capacity of the state to deliver on Indigenous rights, and highly dependent on prescriptive government funding, pursue market strategies to achieve self-determination. Economic development is a means to an end: it provides a pathway to financial sustainability. However, the pursuit of economic development agendas has not fundamentally changed the objectives of Aboriginal organisations in relation to their distinctive role in society in relation to Aboriginal peoples and their rights to selfdetermination and community development. 
So the temporary alignment between neoliberal and indigenous political projects serves certain ends. For example, economic development is a means to which indigenous peoples can become significant economic actors. Bell points to the case of Waikato-Tanui and Ngāi Tahu. HowardWagner points to similar motivation in the case of the economic agendas of the Darkinjung Local Aboriginal Land Council and Awabakal Ltd.

In Chapter 16, Maria Bargh progresses this argument in relation to indigenous entrepreneurship and economic development, bringing to the fore critical considerations. As Bargh notes, this is not simply a case of 'a group of elite Māori recognised by the Crown as economic actors, indoctrinated in neoliberal thought and a marginalised underclass of Māori resistance'. Moving beyond the binary or conceptualisations of Māori enterprise and Māori as 'only either champions or victims of neoliberal policies and practices', Bargh explores the 'areas of a diverse economy that are forging other alternative neoliberal or non-neoliberal worlds'. It is more instructive to consider what Māori want from economic and political activity and the ways in which they are agents in managing neoliberalism's constraints and pursuing its possibilities (Bargh, this volume, Chapter 16). For example, Māori agency is evident in the non-market opportunities that Bargh shows them as pursuing, as well as in the ascription of 'legal personhood' to a mountain as part of the Tühoe Treaty settlement.

\section{Organisation of the book}

This collection is divided into three sections. The first teases out nuances in relation to indigenous rights and recognition in the neoliberal age. The contributors to the first section of the book also focus on the connection between governing, policy and neoliberalism, and illustrate the technologies mobilised to produce indigenous subjects capable of adjusting to increasingly changing and uncertain circumstances.

In Chapter 2, Isabel Altamirano-Jiménez shows how the introduction of matrimonial property rights on reserves in Canada not only functions to support the economic structure of the settler liberal state but also blames indigenous people for their circumstances and the 'backwardness' of their cultures. 
Similarly, in Chapter 3, Cathy Eatock illustrates how resilience is used to terminate services in smaller remote Aboriginal communities in Australia and to impose private property for the purposes of fighting poverty. Building on Moreton-Robinson (2009), Eatock contends that resilience becomes a means to discipline Indigenous welfare recipients to take responsibilities for themselves while the state moves away from recognition.

In Chapter 4, Avril Bell focuses on the nature of the recognition of Māori by local government. Bell argues that neoliberal politics has shaped and constrained the recognition that is on offer. She introduces a number of important considerations taken up in more detail throughout the collection. Like O'Sullivan, she notes that devolution has led to Māori delivering services previously delivered by the state. Like McCormack, she suggests that the spaces opened up for Māori reflect market rationalities. She sees significant problems with the combining of neoliberalism and indigenous political projects because of the constraints it places on Māori governance models and the failure of those models to gain greater political power. Local government is for Bell emblematic of the failure of the Crown to adequately recognise Māori as partners to the Treaty of Waitangi.

In this chapter, neoliberalism comes to be more clearly identified as cooperative with recognition rather than opposed to it.

In Chapter 5, Mandy Yap and Eunice Yu note that, in Australia, policies aimed at improving Indigenous wellbeing have attempted to measure Indigenous performance according to hegemonic ideals and values that fail to consider Indigenous peoples' historical experiences of colonisation. The authors offer a broader perspective of Indigenous self-determination through working with the Yawuru community in Broome to model co-production of knowledge from the ground up.

Importantly, Yap and Yu draw on important empirical research to show that child welfare policy is determined by neoliberal values, but that Indigenous self-determination and wellbeing derives from different principles. This is an important contribution to this collection, by clearly including a discussion of Indigenous values as an alternative to neoliberal values. Although the chapter as a whole does not directly consider neoliberalism, it is a key part of this volume, which aims to cover the 
issue of neoliberalism and indigenous rights in the contemporary world. Considering this question only from the perspective of the state and nonindigenous frameworks would be limiting.

While a number of the authors in the second section, 'Pendulums and contradictions in neoliberalism governing everything from Indigenous disadvantage to Indigenous economic development in Australia', have contributed to our understanding of changes to Indigenous rights and recognition in Australia over the past decade or so, the chapters in this section provide a more in-depth understanding of the Indigenous policy in Australia in the present moment, giving more detailed consideration to this moment in the context of the neoliberal age.

In Chapter 6, Will Sanders draws attention to the demise of Indigenous representation in the Australian public policy space, as well as the narrowing administrative location of Indigenous-specific programs, following the abolition of ATSIC. In doing so, he revisits some of his arguments about how the former ATSIC and Indigenous organisations could together be thought of as moving 'towards an Indigenous order of Australian government' (Sanders 2002). He points to the importance of a strong Indigenous presence within Australian political institutions, arguing that Australia needs a strong Indigenous representative body within its political institutions for the very simple reason that some law and governmental authority in Australia must flow from Indigenous peoples and their precolonial history. He also explains how Australian public policy is still trying to recover from the abolition of ATSIC, over a decade on.

Sanders' deeply knowledgeable account of the end of ATSIC and the various new arrangements that have succeeded is a discussion of the profound changes in policy and Indigenous representation. He adopts a slightly different approach from some researchers, including in his rejection of the framing of neoliberalism as an immoveable force. While monolithic accounts of neoliberalism do foreclose possibilities for change, recent moves towards representation continue to show the importance of decolonising peoples' ideas in the contemporary world and how this challenges conventional framings of neoliberalism as opposed to such moves. 
In Chapter 7, Karen Soldatic explores the effects of significant policy change in national disability income support, with particular reference to the impact of neoliberal restructuring of welfare regimes on Aboriginal and Torres Strait Islander people with disabilities in regional centres across Australia. Commonly referred to as welfare-to-work measures, there has been ample research globally on their implications for non-disabled income benefit recipients, though research on their impact on people with disabilities is minimal, and almost non-existent in terms of the effects on indigenous people living with disabilities. Income support measures have been critically important for regional towns experiencing ongoing economic change. Yet, we do not know how regional communities respond to these policy changes, nor do we understand how national disability income support policy impacts upon the wellbeing of Aboriginal and Torres Strait Islander people with disabilities living in regional Australia. Soldatic maps some of the issues that emerged out of interviews with disability service providers and advocacy groups responding to the changes on the ground.

In Chapter 8, Shelley Bielefeld explains the reduction of Indigenous peoples' rights in the context of cashless welfare transfers as a neoliberal intervention in the lives of Indigenous welfare recipients, tracking the introduction of the federal government trial of a Healthy Welfare Card following the Forrest Review in 2014. She examines the neoliberal rationalities underlying the intent of the Review and the legislation that saw the Healthy Welfare Care trialled in communities with significant numbers of Indigenous welfare recipients: Ceduna, Kununurra and Wyndham. She explains how Indigenous welfare recipients are tasked with 'responsibilisation'. However, Bielefeld also presents an alternative approach, or what she refers to as a reparations framework for Australia's First Peoples, funded by a kind of integrity tax, arguing that a new 'politics of distribution' (Ferguson 2015: 10) is long overdue.

In every policy field, there are some well-worn truths about how some of the stubborn features of policy areas are generated by characteristics that arise from aspects of neoliberal governance. This is especially true of Aboriginal housing in Australia where the way state and federal governments address problems of Aboriginal homelessness, high levels of crowding and poor-quality housing is seen to contribute to and perpetuate them. State recognition of Indigenous housing rights is characterised by tensions, contradictions and policy turnarounds in which the imposition of neoliberal ideologies of normalisation come up against the realities 
of culture and place. The result is policy instability and problematic outcomes for Aboriginal individuals and communities. In Chapter 9, Daphne Habibis analyses how these dynamics have played out in efforts to improve remote Aboriginal housing over the last three decades. She explains how, following the demise of ATSIC, Indigenous housing policy in Australia swung away from local provision by Aboriginal organisations towards the mainstreaming of housing delivery. In remote communities, this culminated in the National Partnership Agreement on Remote Indigenous Housing (NPARIH). Drawing on an investigation into the NPARIH reforms, Habibis suggests that in the closing years of NPARIH, policy is now swinging away from state to community provision. She reflects on how this policy roundabout impacts on Aboriginal communities and what can be done to address this.

In Chapter 10, Alex Page turns his attention to a more detailed consideration of the racialised effects of the IAS on Aboriginal organisations. His chapter points to the precarious or 'fragile' position of the Indigenous sector with minimal accountability of, and increased control by, the Australian Government at the federal level. He also points to how the IAS contributes to the undermining of the Indigenous sector's important role and achievements as an expression of Indigenous selfdetermination.

Along with many of the authors in this collection, Patrick Sullivan turns his attention to the intensification of techniques of control beyond traditional bureaucratic practice into every facet of social life under new or neoliberal public management, and how these impact upon previously relatively autonomous and largely self-governing organisations, such as Indigenous corporations. However, in Chapter 11, Sullivan not only draws on a case study of the effects of neoliberal public management, showing its importance, he equally demonstrates the importance of critically analysing contemporary public management as a coercive extension of the state, as well as considering alternatives. In his chapter, Sullivan aims to do so broadly, while tying this analysis to the position of Indigenous civil organisations in the Australian polity as a whole.

Going in a slightly different direction to Sullivan, in the next chapter Deirdre Howard-Wagner tracks the history of urban Aboriginal organisations, and explains the distinctive role they play in society in relation to urban Aboriginal peoples and their rights to self-determination and community development. In Chapter 12, Howard-Wagner explains how Aboriginal 
people in Newcastle had found organisational mechanisms for exercising their rights to self-determination and autonomy in matters relating to their internal and local affairs. She argues that urban Aboriginal organisations in this locality have proven essential to advocacy, the maintenance of community development and the creation of new social infrastructure, with their success resulting in both economic and social outcomes. She then goes on to explain how NPM reforms to social service delivery at the federal and state level, alongside changes in Indigenous policy over the last 12 years-including the new mainstreaming of Aboriginal service delivery after the abolition of ATSIC in 2005 and the Community Development Employment Projects (CDEP) program shortly after, and, more recently, the Indigenous Advancement Strategy (IAS) — has affected the capacity of urban Aboriginal organisations in Newcastle to perform these roles. She draws on a case study of these organisations in Newcastle to explain how new agendas to pursue economic development and become financially sustainable are a means to an end in terms of pursuing self-determination in the neoliberal age.

The final section in this collection is titled 'The dynamic relationship Māori have had with simultaneously resisting, manipulating and working with neoliberalism in New Zealand', and the authors of these chapters examine this relationship from a range of perspectives.

In Chapter 13, Dominic O'Sullivan argues that neoliberal reforms in New Zealand have had a significant but inconsistent influence on Māori legal, political, economic and cultural opportunities. He suggests that, despite a range of negative impacts for Māori (e.g. in the area of unemployment rates), the policy measures used to reduce the size of the state-created opportunities for some Māori to increase their collective wealth. He suggests that Māori delivery of public services has produced enhanced self-determination. He outlines the relationship between Tūhoe and the state as evidence of the creation of new relationships, which, O'Sullivan argues, were not previously possible on a significant scale.

O'Sullivan provides an excellent discussion of the many complex issues surrounding the possibilities and challenges created by Māori interaction with neoliberal regimes. His chapter concerns a different context with very different dynamics. The questions of agency and opportunity are very different to the coercive paternalistic form that Australian neoliberalism has taken. Its conclusions are obviously contested by others in the volume, but it is clearly in conversation with the other chapters. O'Sullivan's 
argument that ' $[\mathrm{t}]$ he possibilities for Māori self-determination are broad and multifaceted. They exist beyond the neoliberal paradigm, as much as they exist within it' makes an important contribution to the perspectives in this volume.

In Chapter 14, Louise Humpage argues that the Māori political party has begun to achieve its goals in social policy for supporting Māori, but the political constraints it faces ultimately undermine the party's ability to hinder the broader running of neoliberalism. Humpage provides a detailed analysis of the Māori Party's social policy initiative, 'Whānau Ora', and argues that while the initiative has challenged aspects of neoliberalism, it has also extended neoliberalism. She concludes that compromising political relationships, like that between the Māori Party and the National Party, ultimately makes it less likely that some indigenous peoples will challenge neoliberal principles and policies in the future.

In Chapter 15, Fiona McCormack explores the case of fisheries management in New Zealand and in particular the introduction of the Quota Management System in 1986 as an example of market environmentalism. The individual transferable quota within the system, McCormack argues, is based on a neoliberal understanding that private property rights are superior to other forms of rights. She highlights how wealth, or a least money, can be generated from trading in quota rather than actual fish and can encourage these forms of market behaviours. McCormack argues that new class distinctions are therefore created among Māori, with some involved in trading quota and others trying to maintain fishing livelihoods. She concludes with a note of hope-that alongside the new class distinctions there are examples of Māori efforts to 'Māorify the economy', making the rolling out of neoliberalism an incomplete and contested process.

In her chapter, Maria Bargh argues there has been increasing recognition of Māori enterprises and of the Māori economy in a neoliberal age, which has been supported by some levels of political recognition particularly facilitated by the Māori Party. This recognition has led to criticisms of the emergence of a Māori neoliberal elite. In Chapter 16, Bargh argues however that this dichotomy of Māori neoliberal elite versus victims/ resistors does not provide a full picture, and many of those people and entities labelled neoliberal are involved in numerous non-neoliberal activities. Highlighting these diverse activities, Bargh encourages an awareness and attentiveness to the many possibilities already existing outside of neoliberalism. 


\section{References}

Altamirano-Jiménez I (2004). North American first peoples: Slipping up into market citizenship? Citizenship Studies, 8(4):349-65, doi.org/10.1080/1362 102052000316963.

Altamirano-Jiménez I (2013). Indigenous encounters with neoliberalism: Place, women, and the environment in Canada and Mexico, UBC Press.

Altamirano-Jiménez I (2014). Indigeneity, law and performance in the atlantic coast of Nicaragua. In Gilbert H \& Gleghorn C (eds), Recasting commodity and spectacle in indigenous America, Institute for Advanced Studies, University of London Press, London.

Australian Government (2011). The benefits of township leasing in the Northern Territory, Fact Sheet, www.fahcsia.gov.au/sa/indigenous/progserv/ land/township_leasing/Pages/factsheet_3.aspx.

Banting K (1996). Social policy. In Doern, GB, Pal L \& Tomlin B (eds), Border crossings: The internationalization of Canadian policy, Oxford University Press, Toronto.

Bargh M (2006). Changing the game plan: The Foreshore and Seabed Act and constitutional change. Kötuitui: New Zealand Journal of Social Sciences Online, 1(1):13-24, doi.org/10.1080/1177083X.2006.9522408.

Bargh M (2007). Māori development. In Bargh M (ed.), Resistance: An indigenous response to neoliberalism, Huia, Wellington.

Barnett C (2005). The consolations of 'neoliberalism'. Geoforum, 36(1):7-12.

Barrera J (2017). Email reveals Trudeau Liberals playing games with UDRIP. APTN National News, 11 May, aptnnews.ca/2017/05/11/email-revealstrudeau-liberals-playing-double-game-on-undrip-saganash/.

Bashevkin S (2003). Do urban governance changes affect women's representation? A preliminary look at Toronto and London. Canadian Issues, February:23-5.

Bielefeld S (2012). Compulsory income management and Indigenous Australians, UNSW Law Review, 35(2):522-60.

Bradley G (2014). Mighty River signs secret Lake Taupo deal with Māori Trust. New Zealand Herald, 22 December, www.nzherald.co.nz/business/news/ article.cfm?c_id=3\&objectid=11377982. 
Brenner N, Peck J \& Theodore N (2010). Variegated neoliberalization: geographies, modalities, pathways. Global Networks, 10(2):182-222, doi.org/ 10.1111/j.1471-0374.2009.00277.x.

Brodie J (2008). We are all equal now: Contemporary gender politics in Canada. Feminist Theory, 9(2):145-64.

Brown W (2003). Neoliberalism and the end of liberal democracy, Theory and Event, 7(1), doi.org/10.1353/tae.2003.0020.

Cahill D (2010). 'Actually existing neoliberalism' and the global economic crisis. Labour \& Industry: a journal of the social and economic relations of work, 20(3):298-316.

Clarke J (2004). Dissolving the public realm: The logics and limits of neoliberalism. Journal of Social Policy, 33(1):27-48, doi.org/10.1017/S0047279403007244.

Coates K (2016). Indigenous support for development is being heard. Inside Policy, MacDonald Laurier Institute, June, www.macdonaldlaurier.ca/ indigenous-support-for-development-is-being-heard-ken-coates-in-insidepolicy/.

Coulthard G (2007). Subjects of empire: Indigenous peoples and the 'politics of recognition' in Canada. Contemporary Political Theory, 6(4):437-60, doi.org/ $10.1057 /$ palgrave.cpt.9300307.

Coulthard G (2014). Red skin, white masks: Rejecting the colonial politics of recognition, University of Minnesota Press, doi.org/10.5749/minnesota/ 9780816679645.001 .0001 .

Daes EI (2003). Article 3 of the Draft UN Declaration on the Rights of Indigenous Peoples: Obstacles and consensus. Paper presented at the Rights and Democracy Seminar of Experts on the Right to Self-Determination of Indigenous Peoples, New York.

Dean M (2002). Powers of life and death beyond governmentality. Cultural Values 6(1-2):119-38, doi.org/10.1080/1362517022019775.

Dean M (2004). Governmentality: Power and rule in modern society. SAGE Publications, London.

Durie M (2004). Public sector reform, indigeneity, and the goals of the Mãori development, Commonwealth Advanced Seminar.

Fairhead J, Leach M \& Scoones I (2012). Green grabbing: A new appropriation of nature? Journal of Peasant Studies 39(2):237-61, doi.org/10.1080/030661 50.2012.671770. 
Ferguson J (2015). Give a man a fish: Reflections on the new politics of distribution, Duke University Press, Durham \& London, doi.org/10.1215/ 9780822375524 .

Fine B \& Saad-Filho A (2017). Thirteen things you need to know about neoliberalism. Critical Sociology 43(4-5):685-706.

Goldberg DT (2002). The racial state, Blackwell, Massachusetts.

Goldberg DT (2009). The threat of race: Reflections on racial neoliberalism, Blackwell, Massachusetts.

Gover, K (2015). Settler state theory, 'CANZUS' and the United Nations Declaration of the Rights of Indigenous Peoples. European Journal of International Law 26(1):345-73.

Green K (2002). Welfare reform in Australia and the United States: Tracing the emergence and critiques of the new paternalism and mutual obligation. The Drawing Board: An Australian Review of Public Affairs 3(1):15-32.

Hall S (2003). New Labour has picked up where Thatcherism left off: Blair's project has been to absorb social democracy into neoliberalism. The Guardian, 6 August: 1 .

Harvey D (2006). Neo-Liberalism as creative destruction. Geografiska Annaler: Series B, Human Geography 88(2):145-58, doi.org/10.1111/j.0435-3684. 2006.00211.x.

Howard-Wagner D (2006). Post Indigenous rights: the political rationalities and technologies governing Federal Indigenous Affairs in Australia in the contemporary period. PhD thesis, University of Newcastle, Australia.

Howard-Wagner D (2007). Restoring social order through tackling passive welfare: The statutory intent of the Northern Territory National Emergency Response Act 2007 (Cth) and Social Security and Other Legislation Amendment (Welfare Payment Reform) Act 2007 (Cth). Current Issues in Criminal Justice, $19: 243$.

Howard-Wagner, D (2008). Legislating away indigenous rights. Law Text Culture $12: 45$.

Howard-Wagner D (2009). Whiteness, power relations, resistance and the practical recognition of Indigenous rights in Newcastle. Theory in Action, 2(1):40-65, doi.org/10.3798/tia.1937-0237.08028. 
Howard-Wagner D (2010a). The state's Intervention in Indigenous affairs in the Northern Territory: Governing the Indigenous population through violence, abuse and neglect. In Browne C \& McGill J (eds), Violence in France and Australia: Disorder the postcolonial welfare state, Sydney University Press, Australia.

Howard-Wagner D (2010b). From denial to emergency: Governing Indigenous communities in Australia. In Fassin D \& Pandolfi M (eds), Contemporary States of Emergency: The Politics of Military and Humanitarian Interventions, Zone Books.

Howard-Wagner D (2012). Reclaiming the northern territory as a settler-colonial space. Arena Journal, 37/38:220.

Howard-Wagner D (2015). Child wellbeing and protection as a regulatory system in the neoliberal age: Forms of aboriginal agency and resistance engaged to confront the challenges for aboriginal people and community-based aboriginal organisations. Australian Indigenous Law Review 19(1):88-102.

Howard-Wagner D (2017). Governance of indigenous policy in the neoliberal age: Indigenous disadvantage and the intersecting of paternalism and neoliberalism as a racial project. Ethnic and Racial Studies 41(7):1332-51, doi.org/10.1080/01419870.2017.1287415.

Howard-Wagner D (in press). 'Moving from transactional government to enablement' in Indigenous service delivery. Australian Journal of Social Issues.

Howard-Wagner D \& Kelly B (2011). Containing Aboriginal mobility in the Northern Territory: From protectionism to interventionism. Law Text Culture $15: 102$.

Kelsey J (2005). Māori, Te Tiriti, and globalisation: The invisible hand of the colonial state. In Belgrave M, Kawharu M \& Williams D (eds), Waitangi revisited, Oxford University Press, Oxford.

Larner W, Heron RL, \& Lewis N (2007). Co-constituting 'after neoliberalism': Political projects and globalizing governmentalities in Aotearoa/New Zealand. In England K \& Ward K (eds), Neoliberalization: States, networks, peoples, Blackwell, Oxford, doi.org/10.1002/9780470712801.ch9.

Li T (2010). Indigeneity, capitalism and the management of dispossession. Current Anthropology, 51(3):385-400, doi.org/10.1086/651942.

Lightfoot S (2012). Selective endorsement without intent to implement: Indigenous rights and the anglosphere. The International Journal of Human Rights, 16(1):100-22. doi.org/10.1080/13642987.2012.622139. 
Lindroth M (2014). Indigenous rights as tactics of neoliberal governance. Practices of expertise at the United Nations, Social and Legal Studies 23(3):341-61, doi.org/10.1177/0964663914524265.

McCormack F (2011). Levels of indigeneity: The Maori and neoliberalism. Journal of the Royal Anthropological Institute, 17(2):281-300.

McKeen W \& Porter A (2003). Politics and transformation: Welfare state restructuring in Canada. In Clement W \& Vosko S (eds), Changing Canada: Political economy as transformation, McGill-Queen's University Press.

Mead LM (1997). The rise of paternalism. In Mead LM (ed.), The new paternalism: Supervisory approaches to poverty, The Brookings Institution, Washington.

Moreton-Robinson A (2009). Imagining the good indigenous citizen: Race war and the pathology of patriarchal white sovereignty. Cultural Studies Review, 15(2):61-79, doi.org/10.5130/csr.v15i2.2038.

Nadesan M (2008). Governmentality, biopower and everyday life, Taylor and Francis, New York.

New Zealand Government (2007). Ngāti Tüwharetoa, www.govt.nz/treatysettlement-documents/ngati-tuwharetoa/.

Pasternack S (2015). How will capitalism save colonialism: The privatization of reserve lands in Canada. Antipode 47(1):179-96, doi.org/10.1111/anti. 12094.

Peck E (2004). Modernisation: The ten commitments of New Labour's approach to public management? International Public Management Journal 7(1):1.

Postero N (2007). Now we are citizens: Indigenous politics in postmulticultural Bolivia, Stanford University Press.

Razack S (2008). Casting out: The eviction of muslims from western law and politics, University of Toronto Press, Toronto.

Rose N \& Miller P (1991). Political power beyond the state: Problematics of government. British Journal of Sociology 43(2):173-205, doi.org/10.2307/ 591464 .

Sanders W (2002). Towards an Indigenous order of Australian Government: Rethinking self-determination as Indigenous affairs policy, Discussion Paper 230, Centre for Aboriginal Economic Policy Research, The Australian National University, Canberra.

Shore C \& Kawharu M (2014). The Crown in New Zealand. Sites 11(1):17-38, doi.org/10.11157/sites-vol1 1 iss1id267. 
Singh J (2014). Recognition and self-determination approaches from above and below. In Eisenberg A, Webber J, Coulthard G \& Boiselle A (eds), Recognition vs self-determination: Dilemmas of emancipatory politics, UBC Press, Toronto, Vancouver.

Soss J, Fording R \& Schram S (2011). Disciplining the poor: Neoliberal paternalism and the persistent power of race, Chicago University Press, Chicago, doi.org/ 10.7208/chicago/9780226768786.001.0001.

Spronk S (2007). Roots of resistance to urban water privatization in Bolivia: The 'new working class', the crisis of neoliberalism, and public services. International Labor and Working-Class History 71(1):8-28, doi.org/10.1017/ S0147547907000312.

Turnbull M (2017). Speech to Parliament on the 2017 Closing the Gap Report, 14 February 2017, www.pm.gov.au/media/closing-gap-report-statementparliament.

Tūwharetoa Māori Trust Board (2017). Tūwharetoa Māori Trust Board stands by water interests, media release, 5 July 2017, www.tuwharetoa.co.nz/mediastatement-tuwharetoa-maori-trust-board-stands-by-water-interests/.

Vanstone A (2005). Address to National Press Club, 23 February, Canberra.

Venugopal R (2015). Neoliberalism as concept. Economy and Society 44(2):16587.

Wacquant L (2009). Punishing the poor: The neoliberal government of social insecurity, Duke University Press, doi.org/10.1215/9780822392255.

Wacquant L (2010). Crafting the neoliberal state: Workfare, prisonfare, and social insecurity. Sociological Forum 25(2):197-220.

Waitangi Tribunal (2012). National freshwater and geothermal inquiry, Government Print, 2012, forms.justice.govt.nz/search/Documents/WT/wt _DOC_59941926/Wai2358W.pdf.

Williams D (1999). Te Kooti Tango Whenua: The Native Land Court 1864-1909, Huia Publishers, Wellington.

Williams M (2014). On the use and abuse of recognition in politics. In Eisenberg A, Webber J, Coulthard G \& Boiselle A (eds), Recognition vs self-determination: dilemmas of emancipatory politics, UBC Press, Toronto, Vancouver.

Wilson J (2015). Why it's time to stop worrying about paternalism in health policy. In Schramme T (ed.), New perspectives on paternalism and health care, Springer, Switzerland, doi.org/10.1007/978-3-319-17960-5_13. 
Winant $\mathrm{H}$ (2004). The new politics of race: Globalism, difference, justice, University of Minnesota Press, Minneapolis.

Wolfe P (2006). Settler colonialism and the elimination of the native. Journal of Genocide Research 8(4):387-409, doi.org/10.1080/14623520601056240.

Young A (2012). Key on water: no one owns water. NZ Herald, 7 February, www.nzherald.co.nz/nz/news/article.cfm?c_id=1 \&objectid=10783913. 
This text is taken from The Neoliberal State, Recognition and Indigenous Rights: New paternalism to new imaginings, edited by Deirdre Howard-Wagner, Maria Bargh and Isabel AltamiranoJiménez, published 2018 by ANU Press, The Australian National University, Canberra, Australia.

doi.org/10.22459/CAEPR40.07.2018.01 